\title{
Pengembangan Modul Fisika Berbantuan Teknologi Augmented Reality pada Materi Gelombang Bunyi untuk SMA/MA Kelas XI
}

\author{
L. N. Khunaeni*, W. D. Yuniarti, dan M. A. Khalif \\ Prodi Pendidikan Fisika, Universitas Islam Negeri Walisongo Semarang, Indonesia \\ *Email: lilinazwa.la@gmail.com
}

Received: July 27th, 2020. Accepted: August 18th 2020. Published: August 315t, 2020

\begin{abstract}
Abstrak
Penelitian ini bertujuan untuk mengetahui kelayakan modul fisika dengan teknologi Augmented Reality (AR). Penelitian ini mrupakan penelitian R\&D, terdiri dari tahap studi awal, perencanaan, pengembangan, penilaian produk, revisi produk, dan uji coba lapangan. Teknik pengumpulan data yang digunakan adalah observasi dan wawancara pada studi pendahuluan; serta angket untuk validasi ahli materi dan ahli media, validasi guru fisika, dan respons siswa. Berdasarkan analisis data yang dilakukan, diperoleh kesimpulan bahwa kualitas modul fisika sangat baik dengan persentase nilai 95\% dari ahli materi, $86,67 \%$ dari ahli media dan $90 \%$ dari guru fisika. Respons siswa terhadap modul fisika memperoleh persentase 89\% dengan kategori sangat baik. Berdasarkan hasil penelitian, modul fisika berbantuan teknologi Augmented Reality (AR) yang dikembangkan layak dan dapat digunakan dalam pembelajaran fisika.
\end{abstract}

\begin{abstract}
This research aims to determine the appropriateness of a physics module with Augmented Reality (AR) technology. This research is an R\&D research consisting of the initial study stages, planning, development, product assessment, product revision and field trials. Data collection techniques used were observation and interviews during the preliminary study, and questionnaires for validation of material experts and media
\end{abstract}


experts, validation of physics teachers, and student responses. Based on the data analysis, it was concluded that the quality of the physics module was very good with a percentage value of $95 \%$ from material experts, $86.67 \%$ from media experts and $90 \%$ from physics teachers. Student responses to the physics module obtained a percentage of $89 \%$ in the very good category. Based on the research results, the physics module with Augmented Reality (AR) technology developed is appropriate and can be used in physics learning. C2020PERJ

Keywords: Augmented Reality; physics modul; Wave; Sound.

\section{PENDAHULUAN}

Perkembangan pengetahuan dan teknologi pada era revolusi industri 4.0 menjadi tantangan besar bagi manusia. Inovasi baru dalam dunia pendidikan merupakan suatu keniscayaan yang harus dilakukan. Inovasi pendidikan merupakan sebuah penemuan baru yang berbeda dari hal sebelumnya yang berorientasi pada peningkatan kemampuan untuk mencapai tujuan pendidikan (Wijaya, 1992). Perkembangan teknologi dan inovasi pendidikan merupakan salah satu faktor yang berpengaruh terhadap perkembangan kurikulum pendidikan di suatu negara (Azis, 2018; Rulviana, 2018).

Kurikulum yang berlaku di Indonesia saat ini adalah kurikulum 2013. Standar Kompetensi Lulusan (SKL) tertuang dalam kurikulum 2013, meliputi aspek sikap, pengetahuan, dan keterampilan. Proses pembelajaran sebagai bagian integral dari pencapaian SKL yang meliputi aspek sikap, pengetahuan, dan keterampilan mengacu pada pendekatan saintifik. Metode saintifik atau metode ilmiah dilakukan dengan memperbanyak kegiatan pengamatan atau observasi (Bermawi \& Fauziah, 2016).

Pembelajaran saintifik memerlukan alat pendukung baik berupa media pembelajaran, bahan ajar, maupun strategi pembelajaran. Hal ini dilakukan untuk mencapai tujuan dari proses pembelajaran. Tercapainya seluruh tujuan pembelajaran merupakan indikator dari keberhasilan pembelajaran yang dilakukan (Pertiwi, 2015). Media pembelajaran diperlukan untuk mendukung keberhasilan pembelajaran. Media pembelajaran yang baik juga harus mampu menjawab tantangan perkembangan teknologi dan user friendly terhadap pengguna. Salah satu contoh media pembelajaran adalah modul berbasis teknologi (Sujanem, 2012). Modul merupakan salah satu media yang mampu meningkatkan hasil belajar siswa 
(Sukardiyono \& Wardani, 2013; Yusro \& Sasono, 2016). Modul juga berfungsi dalam proses konstruksi pemahaman siswa. Selain itu, modul juga menjadikan siswa sebagai pelajar yang mandiri (Azizah et al., 2019).

Studi lapangan yang telah dilakukan menunjukkan bahwa salah satu faktor permasalahan pembelajaran adalah rasa senang dan nyaman untuk belajar fisika karena siswa akan lebih mudah memahami materi yang disampaikan guru fisika. Pekembangan teknologi dalam pembelajaran di sekolah harus dimanfaatkan untuk mengasah pengetahuan siswa dalam pelajaran fisika, dengan membuat siswa merasa nyaman dan senang saat belajar fisika. Suasana nyaman dan senang dalam proses pembelajaran akan membuat materi lebih mudah dipahami oleh siswa (Supardi et al., 2012).

Augmented Reality atau realitas tambahan merupakan teknologi multimedia yang saat ini gencar dikembangkan, bahkan pada bidang pendidikan. Augmented Reality adalah aplikasi yang menggabungkan antara dunia nyata dengan dunia maya dalam bentuk dua dimensi maupun tiga dimensi (Mustaqim \& Kurniawan, 2017). Pengembangan media seperti elearning mempunyai faktor hambatan, di antaranya biaya sarana prasarana dan perawatan sarana prasarana berbasis komputer masih cukup tinggi dan penggunaan komputer yang belum cukup memenuhi standar jumlah untuk siswa yang ada (Mustaqim \& Kurniawan, 2017).

Augmented Reality merupakan sebuah terobosan pada bidang teknologi yang dapat digunakan untuk memperkecil kelemahankelemahan yang dimiliki oleh media buku maupun e-learning (Bakri, Muliyati, et al., 2018). Lee (2012) menyatakan bahwa augmented reality mempunyai potensi yang tinggi dalam menarik, menginspirasi, dan memotivasi siswa untuk menambah nilai ilmu dan melakukan pengawasan dari berbagai prespektif yang berbeda, yang sebelumnya tidak menjadi bahan acuan utama dalam dunia pendidikan(Lee, 2012)(Lee, 2012)(Lee, 2012)(Lee, 2012)(Lee, 2012)(Lee, 2012)(Lee, 2012).

Teknologi augmented reality telah diterapkan dalam bidang pendidikan terutama dalam pembelajaran fisika. Teknologi AR dimanfaatkan dalam media pembelajaran berbasis android (Ambarwulan \& Muliyati, 2016), serta diintegrasikan dalam buku teks pada berbagai materi fisika (Bakri et al., 2019; Bakri, Ambarwulan, et al., 2018; Hafi \& Supardiyono, 2018). Teknologi AR dapat menjawab tuntutan kurikulum 2013. Hadirnya teknologi AR memungkinkan adanya integrasi teknologi grafis, visual atau audio visual, dan teks ke dalam buku cetak. 
Gelombang bunyi merupakan salah satu materi fisika yang kaya akan konsep dan perlu divisualisasikan dalam bentuk video maupun animasi. Visualisasi konsep ini berfungsi mengkonstruksi pengetahuan dan mempermudah pemahaman konsep siswa. Berdasarkan uraian latar belakang tersebut, perlu dikembangkan bahan ajar fisika materi gelombang bunyi dalam bentuk modul yang dilengkapi dengan augmented reality. Modul berbantu teknologi augmented reality dikembangkan untuk membantu siswa memahami materi gelombang bunyi.

\section{METODE}

Penelitian ini merupakan penelitian R\&D (research and Development), yang menghasilkan produk berupa modul fisika berbantuan teknologi augmented reality pada materi Gelombang Bunyi. Model pengembangan diadaptasi dari Borg and Gall. Alur pengembangan modul Fisika ditunjukkan pada Gambar 1.

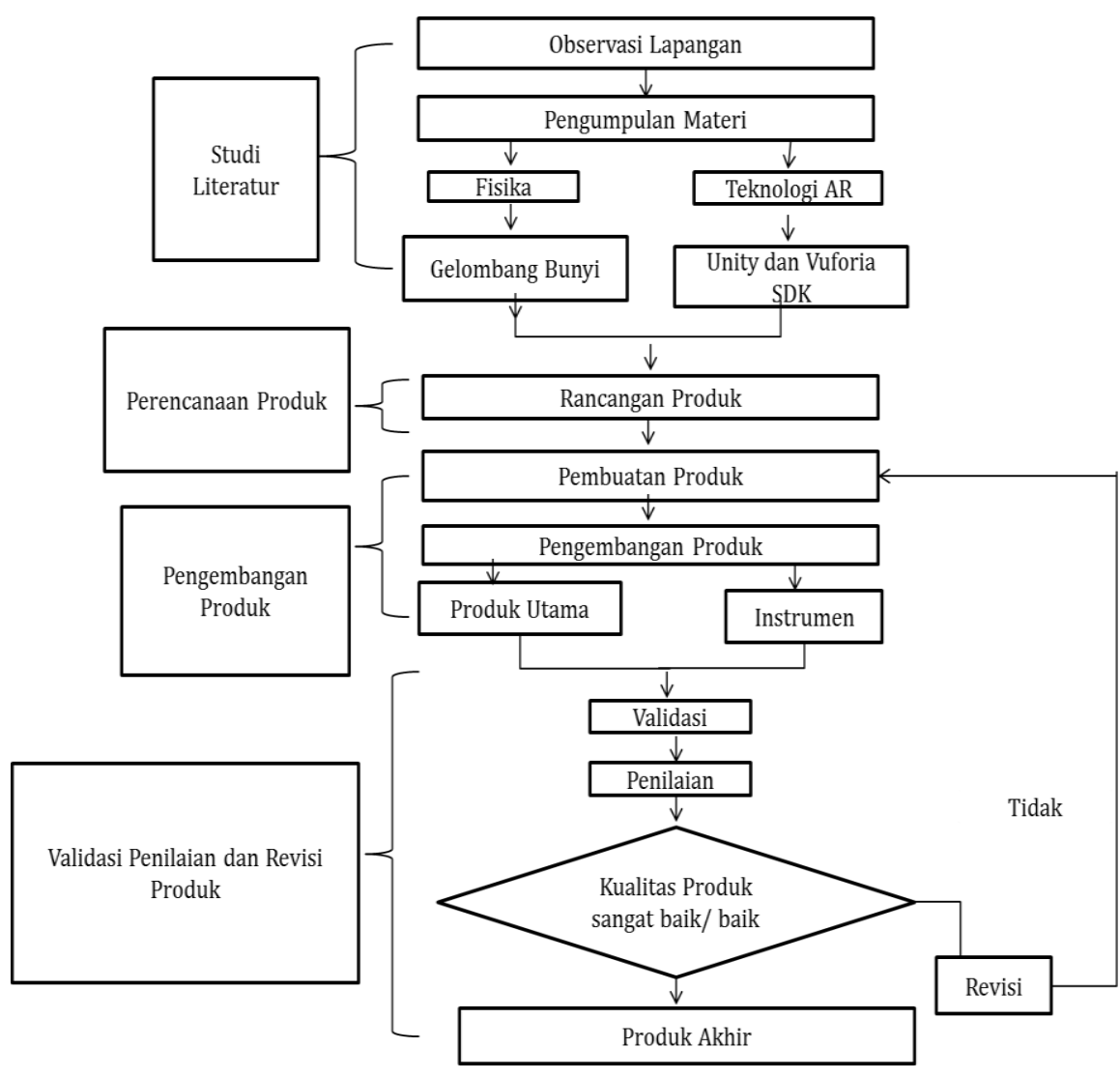

Gambar 1. Alur Pengembangan 
Metode pengumpulan data dalam penelitian ini menggunakan wawancara, observasi, dan angket. Wawancara dan observasi digunakan pada studi pendahuluan untuk menemukan permasalahan dan need assessment. Wawancara dilakukan kepada siswa dan guru fisika. Angket digunakan untuk validasi ahli materi, ahli media, guru fisika, serta mengetahui respons siswa terhadap media yang dikembangkan.

Instrumen pengumpulan data yang digunakan menggunakan skala likert dalam bentuk cheklist dengan lima skala.

Teknik analisis data yang digunakan adalah analisis kelayakan modul berdasarkan ahli materi, ahli media, dan praktisi pendidikan (guru fisika) serta analisis respons siswa terhadap modul yang dikembangkan. Analisis kelayakan dilakukan sebagai berikut:

1. Menjumlahkan skor total setiap aspek penilaian

2. Menghitung rata-rata skor setiap aspek penilaian

3. Menghitung persentase kelayakan setiap aspek

4. Menghitung persentase kelayakan seluruh aspek pada masing-masing validator dan mengkategorikan hasil validasi berdasarkan kriteria kelayakan pada Tabel 1.

Analisis respons siswa dilakukan sebagai berikut:

1. Menjumlahkan seluruh skor penilaian
2. Menjumlahkan seluruh skor penilaian oleh seluruh siswa

3. Merata-rata hasil respons siswa dan mengkategorikan berdasarkan kriteria kelayakan pada Tabel 1.

Tabel 1. Kriteria Kelayakan (Akbar, 2013)

\begin{tabular}{cc}
\hline Persentase $(\%)$ & Kategori \\
\hline $81 \leq \mathrm{P} \leq 100$ & Sangat Baik \\
$61 \leq \mathrm{P} \leq 80$ & Baik \\
$41 \leq \mathrm{P} \leq 60$ & Cukup \\
$21 \leq \mathrm{P} \leq 40$ & Kurang Baik \\
$0 \leq \mathrm{P} \leq 20$ & Tidak Baik \\
\hline
\end{tabular}

\section{HASIL DAN PEMBAHASAN}

Modul fisika berbantuan
teknologi augmented reality dikembangkan untuk materi Gelombang Bunyi. Produk yang dikembangkan berupa modul fisika dalam bentuk hard copy dan aplikasi AR yang diakses melalui smartphone. Modul dikembangkan dengan komponen sebagai berikut: sampul; ucapan terima kasih; kata pengantar; tinjauan isi buku; daftar isi; peta konsep; KI, KD dan Indikator; fitur modul; kamu harus tahu; rangkuman; kunci jawaban; daftar pustaka; daftar notasi dan simbol. Desain aplikasi AR Gelombang Bunyi diberikan dalam bentuk diagram deskripsi interaksi antara pengguna dan sistem. Pengguna masuk ke aplikasi kemudian menu utama akan muncul. Menu utama meliputi menu download buku AR, menu akses kamera, menu tentang aplikasi dan menu keluar untuk 
meninggalkan aplikasi. Diagram rancangan aplikasi dapat dilihat pada Gambar 2. Instalasi aplikasi AR dituangkan dalam flow chart pada Gambar 3.

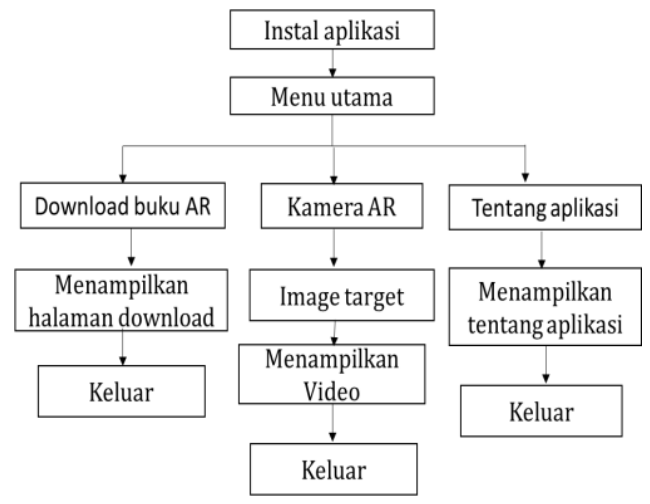

Gambar 2. Diagram Rancangan Aplikasi

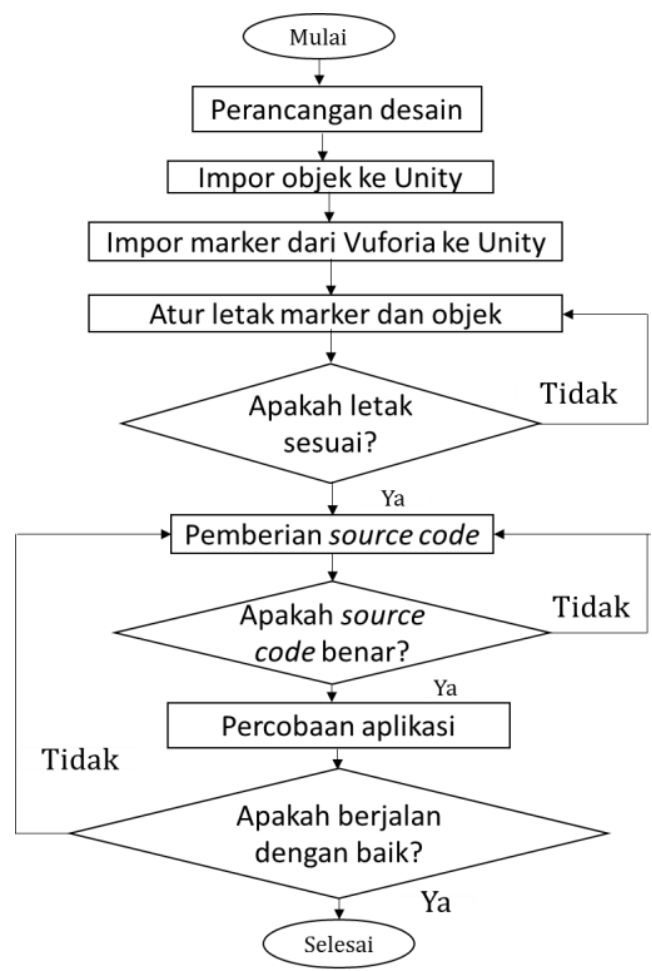

Gambar 3. Alur Proses Aplikasi (Yuniarti, 2019)
Materi yang terdapat pada aplikasi AR Gelombang Bunyi ini berkapasitas 69 KB. Media yang disajikan dalam aplikasi AR Gelombang Bunyi menggunagakan model Based Tracking Marker. Pada model Based Tracking Marker, dibutuhkan marker untuk menampilkan objek yang dimuat oleh sebuah materi. Spesifikasi hardware yang digunakan untuk menjalankan aplikasi Unity 3D versi 2017.3.1f dalam pembuatan aplikasi AR Gelombang Bunyi adalah: Sistem operasi : Windows 10 SPI+,8,10, 64-bit, x64 based Processor; Prosessor : $\operatorname{Intel}(\mathrm{R})$ Core(TM) i5 CPU M540 2.53 GHz; RAM 4 GB. Software yang digunakan untuk menjalankan aplikasi AR Gelombang Bunyi adalah OS Android minimum Jelly Bean 4.1 dan device handphone memiliki penyimapanan ruang minimum 512 MB. Pada aplikasi AR Gelombang Bunyi terdapat 5 media berupa gambar yang dapat discan kemudian akan muncul video pembelajaran yang sudah disediakan untuk beberapa sub bab.

Produk divalidasi oleh ahli materi dan ahli media yang kompeten di bidangnya. Validasi ahli dilakukan oleh dua dosen fisika UIN Walisongo Semarang. Aspek materi terdiri atas empat indikator, yaitu: kelayakan isi, kemenarikan isi, kebahasaan, dan penyajian. Aspek media terdiri atas enam indikator, yaitu: kegrafikan, kualitas tampilan, warna, keterbacaan tulisan, kemenarikan cover, dan 
teknologi AR. Hasil validasi ahli materi tertera pada Tabel 2. Hasil validasi oleh ahli media tertera pada Tabel 3.

Tabel 2. Penilaian Ahli Materi

\begin{tabular}{lcc}
\hline Aspek Penilaian & Skor & $\begin{array}{c}\text { Persentase } \\
\text { Kelayakan } \\
(\%)\end{array}$ \\
\hline Kelayakan Isi & 5 & 100 \\
Kemenarikan Isi & 5 & 100 \\
Kebahasaan & 4 & 80 \\
Penyajian & 5 & 100 \\
\hline Jumlah & 19 & \\
\hline Rata-rata & 4,75 & 95 \\
\hline Katagori & \multicolumn{2}{c}{ Sangat Baik } \\
\hline
\end{tabular}

Modul yang dikembangkan juga divalidasi oleh guru fisika sebagai praktisi pendidikan. Data hasil penilaian modul fisika oleh guru fisika dapat dilihat pada Tabel 4 .

Tabel 3. Penilaian Ahli Media

\begin{tabular}{lcc} 
Aspek Penilaian & Skor & $\begin{array}{c}\text { Persentase } \\
\text { Kelayakan } \\
(\%)\end{array}$ \\
\hline Kegrafikan & 4 & 80 \\
Kualitas tampilan & 4 & 80 \\
Warna & 5 & 100 \\
$\begin{array}{l}\text { Keterbacaan } \\
\text { Tulisan }\end{array}$ & 4 & 80 \\
$\begin{array}{l}\text { Kemenarikan } \\
\text { cover }\end{array}$ & 5 & 100 \\
Teknologi AR & 4 & 80 \\
\hline Jumlah & 26 & \\
\hline Rata-rata & 4,3 & 86,67 \\
\hline Katagori & \multicolumn{2}{c}{ Sangat Baik } \\
\hline
\end{tabular}

Tabel 4. Penilaian Guru Fisika

\begin{tabular}{|c|c|c|c|c|c|}
\hline $\begin{array}{c}\text { Aspek } \\
\text { Penilaian }\end{array}$ & Indikator & Skor & $\begin{array}{l}\text { Skor } \\
\text { Total }\end{array}$ & Rata-rata & $\begin{array}{l}\text { Persentase } \\
\text { Kelayakan } \\
(\%)\end{array}$ \\
\hline Aspek & Kelayakan isi & 5 & \multirow{3}{*}{17} & \multirow{3}{*}{4.25} & \multirow{3}{*}{85} \\
\hline \multirow[t]{2}{*}{ Materi } & $\begin{array}{l}\text { Kemenarikan isi } \\
\text { Kebahasaan }\end{array}$ & $\begin{array}{l}4 \\
4\end{array}$ & & & \\
\hline & Penyajian & 4 & & & \\
\hline Aspek & Kegrafikan & 5 & \multirow{6}{*}{28} & \multirow{6}{*}{4.67} & \multirow{6}{*}{93.3} \\
\hline \multirow[t]{5}{*}{ Media } & Kualitas tampilan & 4 & & & \\
\hline & Warna & 5 & & & \\
\hline & Keterbacaan tulisan & 5 & & & \\
\hline & Kemenarikan cover & 5 & & & \\
\hline & Teknologi AR & 4 & & & \\
\hline Rata-rata & & & 4.5 & & 90 \\
\hline Kategori & & & & & ngat Baik \\
\hline
\end{tabular}

Aplikasi AR telah diinstal pada berbagai merk handphone validator, di antaranya: Xiaomi Redmi, Samsung J7 2016, dan Oppo F7. Aplikasi tidak dapat diinstal pada hp samsung J7 2016. Aplikasi AR Gelombang Bunyi sudah diatur untuk support pada hp yang berversi android jellybead 4.1 dengan RAM $512 \mathrm{MB}$, seharusnya dengan kapasitas minimal tersebut hp samsung J7 2016 sudah bisa terinstal dengan baik. Namun, aplikasi AR tidak bisa diinstal pada hp tersebut. 
Hasil validasi berupa penilaian kritik dan saran digunakan sebagai bahan untuk merevisi produk yang dikembangkan. Setelah direvisi dilakukan uji coba terhadap produk yang dikembangkan. Uji coba dilakukan untuk mengetahui respons siswa terhadap produk yang dikembangkan. Angket respons siswa diberikan kepada siswa yang telah mendapatkan materi Gelombang Bunyi. Uji coba melibatkan 36 siswa dan seluruh siswa telah mengisntal aplikasi AR Gelombang Bunyi sebagai pelengkap modul fisika.

Hasil respons siswa terhadap modul fisika berbantu teknologi augmented reality melalui angket mendapat nilai keseluruhan dengan persentase rata-rata $89 \%$. Siswa memperoleh pengalaman baru dengan adanya modul fisika berbantu teknologi augmented reality pada materi Gelombang Bunyi. Modul sebagai media pembelajaran mampu memberikan pengalaman belajar yang lebih bermakna (Rahayu et al., 2015). Penggunaan augmented reality juga menambah pengalaman baru bagi siswa serta meningkatkan pemahan konsep terhadap fisika (Mahpudin \& Puadi, 2018; Rifqa Gusmida, M. Rahmad, 2016).

Modul yang dikembangkan memiliki karakteristik selfinstruction dan self contained, sehingga siswa dapat secara mandiri menggunakan modul untuk kegiatan belajar mandiri. Self instruction dan self contained merupakan karakteristik dari sebuah modul (Irwandani et al., 2017; Prabowo et al., 2016). Modul dilengkapi dengan materi pendukung untuk mendukung karakteristik modul yaitu self instruction, dan memcapai pembelajaran tuntas.

Hasil uji coba lapangan menunjukkan sebanyak 32 ponsel siswa terinstal aplikasi dan berjalan dengan baik. Akan tetapi, terdapat empat ponsel siswa tidak dapat di instal. Empat ponsel tersebut yaitu satu NOVO Vi, dua Samsung J2 Prime, dan satu Samsung J1 Ace. Spesifikasi empat handphone tersebut sudah melebihi ketentuan versi android yang diatur, yaitu versi andorid terendah yang terpasang adalah android JellyBean 4.1. Handphone siswa yang tidak bisa terpasang adalah NOVO Vi dengan spesifikasi android 7.0 disertai RAM 1 GB , Samasung J2 Prime dengan spesifikasi android 6.0 disertai RAM 1.5 GB, dan Samasung J J1 Ace dengan spesifikasi android 4.4.4 upgradable to 5.1.1 disertai RAM 768 $\mathrm{MB}$.

Modul fisika berbantu teknologi augmented reality memiliki kelebihan dan kekurangan. Kelebihan yang dimiliki adalah modul dapat memvisualisasikan materi pembelajaran melalui video. Konsep-konsep fisika dapat divisualisasikan secara lebih nyata dalam bentuk video dengan menggunakan teknologi augmented reality (Ardhianto et al., 2012). Siswa dapat melihat gambaran bentuk gelombang untuk menambah 
pemahaman. Modul juga dapat digunakan untuk belajar secara mandiri.

Modul fisika berbantu teknologi augmented reality juga memiliki kekurangan. Proses scan gambar yang ada pada modul memerlukan cahaya yang mencukupi. Intensitas cahaya dan jarak kamera sangat mempengaruhi kualitas gambar pada sistem augmented reality (Kustijono \& Hakim, 2014). Pemilihan marker harus memiliki resolusi yang baik agar memudahkan dalam proses scan. Selain itu, tidak semua handphone dapat diinstal aplikasi AR tidak memiliki spesifikasi minimal aplikasi AR Gelombang Bunyi.

\section{KESIMPULAN}

Modul fisika berbantu teknologi Augmented Reality (AR) pada materi Gelombang Bunyi telah dikembangkan dan layak digunakan dalam pembelajaran berdasarkan hasil validasi ahli materi dan ahli media dengan kategori sangat baik. Modul berbantu teknologi AR juga layak digunakan dalam pembalajaran berdasarkan penilaian praktisi pendidikan, yaitu guru fisika SMA/MA dengan kategori sangat baik. Modul berbantu teknologi AR juga diterima oleh siswa berdasarkan respons siswa dengan kategori sangat baik. Modul yang dikembangkan memiliki kelebihan, yaitu: dapat memvisualisasikan materi pembelajaran melalui video, merealisasikan abstraksi konsep fisika dalam bentuk gambar, dan dapat digunakan untuk belajar mandiri. Kekurangan modul adalah: proses scan gambar memerlukan cahaya yang cukup, pemilihan marker harus memiliki resolusi yang baik, dan tidak tidak dapat digunakan pada handphone yang memiliki spesifikasi di bawah android JellyBean 4.1.

\section{DAFTAR PUSTAKA}

Akbar, S. 2013. Instrumen Perangkat Pembelajaran. Bandung: Remaja Rosdakarya.

Ambarwulan, D., \& Muliyati, D. 2016. The Design of Augmented Reality Application as Learning Media Marker-Based for Android Smartphone. Jurnal Penelitian $\mathcal{E}$ Pengembangan Pendidikan Fisika, 2(1): 73-80. p-issn: 2461-0933 \%7C e-ISSN: 2461-1433

Ardhianto, E., Hadikurniawati, W., \& Winarno, E. 2012. Augmented Reality Objek 3 Dimensi dengan Perangkat Artoolkit dan Blender.

Dinamik-Jurnal Teknologi ..., 17(2): $\quad$ 107-117. http://www.unisbank.ac.id/o js/index.php/fti1/article/vie $\mathrm{w} / 1658$

Azis, R. 2018. Implementasi Pengembangan Kurikulum. Inspiratif Pendidikan, 7(1): 44. https://doi.org/10.24252/ip.v 7i1.4932

Azizah, L. M., Poernomo, J. B., \& 
Faqih, M. I. 2019. Pengembangan Modul Pembelajaran Fisika Kekas XI MA/SMA Berbasis Guided Inquiry pada Materi Alat-Alat Optik. Physics Education Research Journal, 1(1): 11. https://doi.org/10.21580/perj 2019.1.1.4006

Bakri, F., Ambarwulan, D., \& Muliyati, D. 2018. Pengembangan Buku Pembelajaran yang Dilengkapi Augmented Reality pada Pokok Bahasan Gelombang Bunyi dan Optik. Gravity : Jurnal Ilmiah Penelitian Dan Pembelajaran Fisika, 4(2): 46-56. https://doi.org/10.30870/gra vity.v4i2.4032

Bakri, F., Muliyati, D., \& Nurazizah, I. 2018. Website E-Learning Berbasis Modul: Bahan Pembelajaran Fisika. Jurnal Wahana Pendidikan Fisika, 3(1): 90-95.

Bakri, F., Oktaviani Marsal, \& Muliyati, D. 2019. Textbooks Equipped with Augmented Reality Technology for Physics Topic in High-School. Jurnal Penelitian $\mathcal{E}$ Pengembangan Pendidikan Fisika, 5(2): 113-122. https://doi.org/10.21009/1.05 206

Bermawi, Y., \& Fauziah, T. 2016. Penerapan Pendekatan

Saintifik Dalam Pembelajaran Di Sekolah Dasar Aceh Besar. Jurnal Pesona Dasar, 2(4): 63-71. Hafi, N. N., \& Supardiyono. 2018. Pengembangan Buku Saku
Fisika Dengan Teknologi Augmented Reality Berbasis Android Pada Materi Pemanasan Global. Inovasi Pendidikan Fisika, 07(02), 306310.

Irwandani, I., Latifah, S., Asyhari, A., Muzannur, M., \& Widayanti, W. 2017. Modul Digital Interaktif Berbasis Articulate Studio'13: Pengembangan pada Materi Gerak Melingkar Kelas X. Jurnal Ilmiah Pendidikan Fisika Al-Biruni, $\quad 6(2)$ : 221. https://doi.org/10.24042/jipf albiruni.v6i2.1862

Kustijono, R., \& Hakim, S. R. 2014. Pengaruh Intensitas Cahaya Dan Jarak Pada Sistem Augmented Reality Objek Animasi. Jurnal Penelitian Fisika Dan Aplikasinya (JPFA), 4(2): 8. https://doi.org/10.26740/jpfa. v4n2.p8-14

Lee, K. 2012. Augmented Reality in Education and Training. Techtrends Tech Trends, 56: 1321.

https://doi.org/https://doi.o rg/10.1007/s11528-012-0559-3

Mahpudin, A., \& Puadi, E. F. W. 2018. Rancang Bangun Augmented Reality (AR) Berbasis Android untuk Pengembangan Media Pembelajaran Fisika. Seminar NAsional Edusaintek FMIPA Unimus, $\quad 550-560$. https://jurnal.unimus.ac.id/in dex.php/psn12012010/article/ view $/ 4255$ 
Mustaqim, I., \& Kurniawan, N. 2017. Pengembangan Media Pembelajaran Pai Berbasis Augmented Reality. Jurnal Edukasi Elektro, 1(1): 36-48. https://journal.uny.ac.id/inde x.php/jee/article/view/13267 /9625

Pertiwi, E. G. 2015. Evaluasi Hasil Pemberian Umpan Balik Positif pada Pendidikan Karakter di MIN 1 Mojokerto. Universitas Muhammadiyah Sidoarjo.

Prabowo, C., Ibrohim, I., \& Saptasari, $\quad$ M. 2016. Pengembangan Modul Pembelajaran Inkuiri Berbasis Laboratorium Virtual. Jurnal Pendidikan - Teori, Penelitian, Dan Pengembangan, 1(6): 10901097.

https://doi.org/10.17977/jp.v $1 \mathrm{i} 6.6422$

Rahayu, W. E., Semarang, U. N., \& Artikel, I. 2015. Pengembangan Modul Ipa Terpadu Berbasis Etnosains Tema Energi Dalam Kehidupan Untuk Menanamkan Jiwa Konservasi Siswa. USEJ - Unnes Science Education Journal, 4(2). https://doi.org/10.15294/usej .v4i2.7943

Rifqa Gusmida, M. Rahmad, N. I. 2016. Development of Physics Learning Media Using Augmented Reality in Gas Kinetic Theory for Senior High School Grade XI. Jurnal Online Mahasiswa Fakultas Keguruan Dan Ilmu Pendidikan Universitas Riau, 3: 1-12.
Rulviana, V. 2018. Implementasi Media Edmodo Dalam Mata Kuliah Pengembangan Kurikulum Sekolah Dasar. Refleksi Edukatika: Jurnal Ilmiah Kependidikan, $8(2)$. https://doi.org/10.24176/re.v $8 \mathrm{i} 2.2361$

Sujanem, R. 2012. Abstrak. Jurnal Nasional Pendidikan Teknik Informatika, 1(2): 103-117.

Sukardiyono, \& Wardani, Y. R. 2013. Pengembangan Modul Fisika Berbasis Kerja Laboratorium dengan Pendekatan Science Process Skills untuk Meningkatkan Hasil Belajar Fisika. Jurnal Pendidikan Matematika Dan Sains, 1(2): 185195.

https://doi.org/10.21831/jpm s.v2i2.2487

Supardi, Leonard, L., Suhendri, H., \& Rismurdiyati. 2012. Pengembangan Media Pembelajaran dan Minat Belajar Terhadap Hasil Belajar Fisika. Jurnal Formatif, 2(1): 7181.

http://journal.lppmunindra.a c.id/index.php/Formatif/artic le/view/86/84

Wijaya, A. C. 1992. Kemampuan Dasar Guru Dalam Proses Belajar Mengajar. Bandung: PT Remaja Rosda Karya.

Yuniarti, W. D. 2019. Dasar-Dasar Pemrograman Dengan Python. Deepublish.

Yusro, A. C., \& Sasono, M. 2016. Penggunaan Modul Ilustratif Berbasis Inkuiri Terbimbing 
Phy. Educ. Res. J. Vol. 2 No. 2 (2020), 83 - 94

Pokok Bahasan Kinematika (JPFK), 2(1):

29.

Gerak Lurus untuk

Meningkatkan Hasil Belajar https://doi.org/10.25273/jpfk dan Kemandirian Siswa Kelas .v2i1.22

VII SMPN 14 Madiun. Jurnal Pendidikan Fisika Dan Keilmuan 